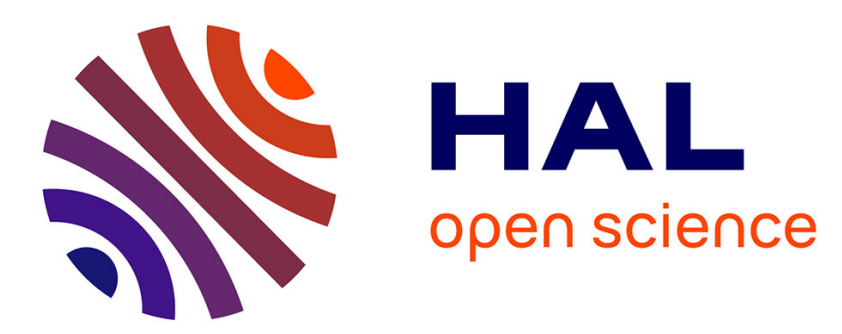

\title{
Perinatal exposure to glyphosate and a glyphosate-based herbicide affect spermatogenesis in mice
}

Thu Ha Pham, Lohann Derian, Christine Kervarrec, Pierre-Yves Kernanec, Bernard Jegou, Fatima Smagulova, Aurore Gély-Pernot

\section{- To cite this version:}

Thu Ha Pham, Lohann Derian, Christine Kervarrec, Pierre-Yves Kernanec, Bernard Jegou, et al.. Perinatal exposure to glyphosate and a glyphosate-based herbicide affect spermatogenesis in mice. Toxicological Sciences, 2019, 169 (1), pp.260-271. 10.1093/toxsci/kfz039 . hal-02061958

\section{HAL Id: hal-02061958}

\section{https://hal-univ-rennes1.archives-ouvertes.fr/hal-02061958}

Submitted on 16 Apr 2019

HAL is a multi-disciplinary open access archive for the deposit and dissemination of scientific research documents, whether they are published or not. The documents may come from teaching and research institutions in France or abroad, or from public or private research centers.
L'archive ouverte pluridisciplinaire HAL, est destinée au dépôt et à la diffusion de documents scientifiques de niveau recherche, publiés ou non, émanant des établissements d'enseignement et de recherche français ou étrangers, des laboratoires publics ou privés. 


\section{Perinatal exposure to glyphosate and a glyphosate-based herbicide affect spermatogenesis in mice.}

Thu Ha Pham ${ }^{1}$, Lohann Derian${ }^{1}$, Christine Kervarrec ${ }^{1}$, Pierre-Yves Kernanec ${ }^{1}$, Bernard Jégou ${ }^{1}$, Fatima Smagulova ${ }^{1}$ and Aurore Gely-Pernot ${ }^{1 \#}$.

${ }^{1}$ Univ Rennes, Inserm, EHESP, Irset (Institut de recherche en santé, environnement et travail)UMR_S 1085, F-35000 Rennes, France

\# Correspondence should be addressed at Irset-Inserm UMR_S 1085, 9 avenue du Pr Léon Bernard, 35000 Rennes, France. E-mail: aurore.gely-pernot@ehesp.fr

Key words: Glyphosate, Roundup, spermatogenesis, reproduction, differentiation 


\begin{abstract}
Glyphosate is the most widely used herbicide in the world. Several studies have investigated the effects of glyphosate and glyphosate-based-herbicides (GBHs) on male reproduction, but there is still little and conflicting evidence for its toxicity. In this study, we analyzed the effects of glyphosate, alone or in formula, on the male reproductive system. Pregnant mice were treated from E10.5 to 20 days postpartum (dpp) by adding glyphosate or a GBH (Roundup ${ }^{\circledR} 3$ Plus) to their drinking water at 0.5 (the acceptable daily intake, ADI dose), 5 and $50 \mathrm{mg} / \mathrm{kg} / \mathrm{day}$. Male offspring derived from treated mice were sacrificed at 5, 20 and 35 days-old (d.o.) and 8 monthsold (m.o.) for analysis. Our result showed that exposure to glyphosate, but not GBH, affect testis morphology in 20 d.o. and decrease serum testosterone concentrations in 35 d.o. males. We identified that the spermatozoa number decreased by $89 \%$ and $84 \%$ in 0.5 and $5 \mathrm{mg} / \mathrm{kg} / \mathrm{day}$ of GBH and glyphosate groups, respectively. Moreover, the undifferentiated spermatogonia numbers were decreased by $60 \%$ in $5 \mathrm{mg} / \mathrm{kg} /$ day glyphosate group, which could be due to the alterations in the expression of genes involved in germ cell differentiation such as Sall4 and Nano3 and apoptosis as Bax and Bcl2. In 8 m.o. animals, a decreased testosterone level was observed in GBH groups. Our data demonstrate that glyphosate and GBHs could cause endocrine-disrupting effects on male reproduction at low doses. As glyphosate has effects at the ADI level, our data suggests that the current ADI for glyphosate could be overestimated.
\end{abstract}




\section{Introduction}

Spermatogenesis is a complex and finely regulated cell differentiation process, taking place in the seminiferous epithelium of the testis and leading to spermatozoa production from stem cells. Spermatogonia, known as $A$ single $(A s)$ spermatogonia, are considered to be the stem cells in mouse. By mitosis, As spermatogonia give rise to two paired then chain of aligned (Aal) spermatogonia referred to be "undifferentiated spermatogonia" because they all retain the stem cell properties. Subsequently $\mathrm{Aal}$ cells differentiate into $A 1$ spermatogonia, which are irreversibly committed toward gamete production (Raverdeau et al. 2012). After meiosis, the specialized cell division process for the production of haploid gametes, and spermiogenesis, a morphological transformation of round spermatids, the elongated spermatids are released in the lumen of seminiferous epithelium. The spermatogenesis process needs functional interactions between germ cells and somatic cells, notably Sertoli cells, involving a complex assortment of endocrine, paracrine and autocrine signaling pathways (Jégou 1993). It is suggested that spermatogenesis is a vulnerable process which can be affected by numerous environmental toxicants (Pryor et al. 2000; Albert and Jégou 2014; Jenardhanan et al. 2016; Gely-Pernot et al. 2018).

Glyphosate (or N-(phosphonomethyl)glycine) so-called glyphosate acid, is a phosphonic acid which is an active ingredient of widely used herbicides. This compound inhibits the 5enolpyruvyl-shikimate-3-phosphate synthase enzyme that is essential for the synthesis of aromatic amino acids in plants (Steinrücken and Amrhein 1980). In 1974, glyphosate was marketed in the United States by Monsanto under the trade name Roundup ${ }^{\circledR}$ (Duke and Powles 2008). Roundup ${ }^{\circledR}$ as well as others glyphosate-based-herbicides (GBHs) contain glyphosate in salt form (to increase the solubility of glyphosate in water), surfactants, adjuvants and water (Mesnage et al. 2015; Myers et al. 2016). Nowadays, GBHs are the most widely used herbicides 
in the world (Benbrook 2016; Myers et al. 2016) and their use may result in exposure of the general public as well as of applicators (Solomon 2016). Glyphosate was detected in urine samples of farmers (Jayasumana et al. 2015), amenity horticulturists (Connolly et al. 2017) as well as in samples of the general public (Conrad et al. 2017; Connolly et al. 2018). In March 2015, glyphosate was classified as a "probable carcinogen for humans" (group 2A) by the International Agency for Research on Cancer (IARC) of the World Health Organization (WHO) (Guyton et al. 2015). However, in November 2015, the European Food Safety Authority (EFSA) did not categorize glyphosate as a carcinogen (European Food Safety Authority (EFSA) 2015) and concluded in 2017 that glyphosate was likely not an endocrine disruptor chemical (EDC) (European Food Safety Authority (EFSA) 2017). Until now, debates about the toxicity of glyphosate are continuing, with a lot of contradictory evidences (Tarazona et al. 2017; Andreotti et al. 2018; Tarone 2018). Therefore, more research studies on the toxicity of glyphosate are urgent and indispensable.

Previous studies suggest that GBHs are EDCs (Richard et al. 2005; Benachour et al. 2007; Mesnage et al. 2015; de Souza et al. 2017). Disturbances in hormonal regulation during prenatal and neonatal periods may induce adverse effects on the male reproductive system (Palanza et al. 2016). In fact, exposure of rats to 50 to $450 \mathrm{mg} / \mathrm{kg} /$ day of GBH (Roundup ${ }^{\circledR}$ ) during pregnancy and lactation affects serum testosterone levels and spermatozoa parameters (Dallegrave et al. 2007; Romano et al. 2012) and causes changes in sexual behavior in the male offspring (Romano et al. 2012). Exposure to GBH during puberty in rats, a known window of vulnerability, induces changes in the progression of puberty, testicular morphology, and reduces testosterone production (Romano et al. 2010). In adult rats, GBH exposure leads to disruption of normal testicular architecture, coupled with a decrease of testosterone secretion as well as abnormal sperm 
properties (Owagboriaye et al. 2017). The toxicity of GBHs is for now attributed to the surfactants and adjuvants that are added during commercial preparations (Tsui and Chu 2003; Mesnage et al. 2013; Johansson et al. 2018). Unlike many studies that focused on GBHs, recent studies on glyphosate alone showed that glyphosate does not affect male reproduction in rat (Dai et al. 2016) or decrease the total sperm production at the high dose of $500 \mathrm{mg} / \mathrm{kg} / \mathrm{day}$ without affecting testosterone level (Johansson et al. 2018). However, some studies support the hypothesis that glyphosate affects sperm parameters in fish (Lopes et al. 2014; Uren Webster et al. 2014; Gonçalves et al. 2018).

In humans, with the exception of attention deficit hyperactivity disorder (ADHD) in children of glyphosate applicators, data from existing epidemiological studies does not support the idea that glyphosate is toxic to reproduction and human development (de Araujo et al. 2016). However, a recent study associates exposure to glyphosate to shortened gestational length (Parvez et al. 2018).

With the goal of testing the impact of glyphosate and GBH toxicity at low doses on the male reproductive function, this study is conducted in mice, a species which has not yet been largely used for evaluating the glyphosate toxicity. The pregnant mice are exposed to purified glyphosate or a GBH, the Roundup ${ }^{\circledR} 3$ Plus, from E10.5 to the end of lactation (20 dpp). Reproductive functions of male offspring were evaluated by analyzing testis morphology, estimating the number of spermatozoa and serum testosterone levels. The number of germ cells and expression of genes involved in their differentiation were also investigated in prepubertal mice. This study highlights the adverse effects of glyphosate and a GBH at low doses on spermatozoa number, testosterone levels and the genes involved in germ cell differentiation. 


\section{Methods}

\section{Chemicals}

The chemicals used are: glyphosate so-called glyphosate acid (N-(Phosphonomethyl)glycine) (Sigma-Aldrich CAS 1071-83-6; product number 89432, purity $\geq 99.2 \%$ ) and Roundup ${ }^{\circledR} 3$ Plus (Monsanto Europe, Belgium) containing $229 \mathrm{~g} / \mathrm{L}$ glyphosate isopropylamine salt $(170 \mathrm{~g} / \mathrm{L}$ glyphosate acid equivalent). By weight, the Roundup ${ }^{\circledR} 3$ Plus formulation contains: $21 \%$ glyphosate isopropylamine salt, about $8 \%$ surfactants and other ingredients, and about $71 \%$ water (CAS 7732-18-5) .The data (in French) is available at: http://www.aude.gouv.fr/IMG/pdf/SCOTTS-Roundup-3-plus cle639faf.pdf. Glyphosate acid is a phosphonic acid resulting from the formal oxidative coupling of the methyl group of methylphosphonic acid with the amino group of glycine (Pubchem).

\section{Animals' exposure and ethic statement}

All animal procedures were performed according to the guidelines for animal models in research defined by the Ethics Committee and approved by the Ministry of France (reference project number is APAFIS\#518). All experiments were performed by AGP who is qualified for laboratory animal care and use. The outbred Swiss mouse strain was used. Four-month-old (m.o.) adult mice were treated for each experimental condition. The day of vaginal plug detection was considered as embryonic day 0.5 (E0.5) and purified glyphosate or a GBH (Roundup ${ }^{\circledR} 3$ Plus) was administered in drinking water from E10.5 to 20dpp at the concentration corresponding to $0.5,5$ and $50 \mathrm{mg} / \mathrm{kg} /$ day of glyphosate based on average water uptake of mice $5 \mathrm{ml} /$ day and average body weight equal to $30 \mathrm{~g}$ at the beginning of experiment. Stock solution of glyphosate 
was prepared as $0.3 \mathrm{mg} / \mathrm{ml}$ water solution and it was diluted and provided fresh twice during the week. Roundup ${ }^{\circledR} 3$ Plus was prepared by diluting the product directly in drinking water. Drinking water was changed twice a week. Control group received water alone. Exposure by drinking water was chosen because the main source of human exposure is the consumption of contaminated water and food (Damalas and Eleftherohorinos 2011; Panzacchi et al. 2018). Control and treated young prepubertal or adult mice were euthanized, and reproductive organs were dissected in 5, 20, 35 days-old (d.o.) and in 8 m.o. mice. Experiments were done in at least 5 animals derived from at least 3 to 4 different litters in each group.

\section{Testosterone quantification}

Serum was collected from ketamine/xylazine-anaesthetized adult animals by terminal cardiac exsanguination and aliquots were stored at $-20{ }^{\circ} \mathrm{C}$. Testosterone levels in the serum were assayed in duplicate using a commercial radioimmunoassay (RIA) based on competitive binding with I125-labeled testosterone (Immunotech, Ref. IM1087, Czech Republic), according to the manufacturer's recommendations.

\section{Epididymis sperm reserves}

Spermatozoa counts were conducted as previously described (Vallet-Erdtmann et al. 2004). Briefly, the mice were euthanized, and the epididymis was dissected, rapidly frozen in liquid nitrogen and stored at $-80^{\circ} \mathrm{C}$ until the sperm heads were counted as follows. The organ was first cut with a scalpel into several fragments and homogenized in $6 \mathrm{ml}$ of $0.15 \mathrm{M} \mathrm{NaCl}$ containing $0.005 \%$ (vol/vol) Triton X-100 (Sigma-Aldrich). After homogenization with three rounds of sonication $(12 \mathrm{kHz})$, an aliquot of the cell suspension was loaded onto a Malassez 
hemocytometer, and spermatozoa heads were counted. The data from at least six controls or treated animals were averaged and plotted.

\section{Analysis of histology and numbers of germ cells and Sertoli cells}

For the histological analysis, testis samples were fixed in Bouin's solution and embedded in paraffin. Histological sections (5- $\mu \mathrm{m}$-thick) were stained with hematoxylin and eosin (H\&E). For immunohistochemistry (IHC), only the adult animals were perfused, and the testes were fixed for $24 \mathrm{~h}$ in $4 \%$ (wt/vol) paraformaldehyde (PFA) and then embedded in paraffin. In order to check the number of undifferentiated spermatogonia on 5 d.o. testes sections, 5 - $\mu$ m-thick testis sections were incubated overnight at $4{ }^{\circ} \mathrm{C}$ with a primary rabbit polyclonal antibody DDX4 diluted at 1:500 (Abcam, ref. Ab13840) and then a secondary Alexa-Chicken anti-rabbit 488 antibody during one hour (dilution 1/500). For IHC on 35 d.o. testis section, 5- $\mu$ m-thick testis sections were incubated overnight at $4{ }^{\circ} \mathrm{C}$ with goat anti-ZBTB16 (R\&D system, ab2944) diluted at 1:500 and rat anti-GATA1 (Santa cruz, ref. sc-265) diluted at 1:50 and then a secondary AlexaChicken anti-goat 488 antibody and a secondary Alexa-donkey anti-rat 594 during one hour (dilution 1/500).

The sections were all counterstained with $0.001 \%$ (vol/vol) 4,6-diamidino-2-phenylindole dihydrochloride (DAPI) and mounted in Vectashield (Vector Laboratories, UK) before microscopy analysis.

To quantify the number of Sertoli cells (GATA1-positive cells) and undifferentiated spermatogonia (ZBTB16-positive cells), we manually counted the cells in an average of 30 sections of seminiferous epithelium at stage VII in control and glyphosate-derived groups. We 
analysed cells in 3 different areas of the testis for each biological replicate. The perimeter of each tubule section was measured by using ImageJ. The values shown indicate the cell counts per micrometer of tubule circumference. For 5 d.o. the germ cells were counted in an average of 96 sections of seminiferous tubules in control and glyphosate-derived groups using 3 different areas of the testis for each biological replicate. Numbers of germ cells were expressed as number of spermatogonia per/square unit of tubule surface. The surface of each tubule section was measured by using ImageJ.

\section{RNA extraction and quantitative PCR}

Total RNA was extracted from 5 d.o. whole testis using the RNeasy plus mini kit according the protocol of the manufacture (Qiagen) and reverse transcription was performed with $1 \mu \mathrm{g}$ of RNA using the iScript ${ }^{\mathrm{TM}}$ cDNA Synthesis Kit according to the manufacturer's instructions (Biorad). The resulting cDNA was diluted 5 times and used for quantitative PCR. The primer sequences used for qPCR are indicated in Table 1. qPCR was performed using the iTaq Universal SYBR Green Supermix (Bio-Rad) according to the manufacturer's instructions on a CFX384 Touch Real-Time PCR Detection system (Bio-Rad). The gene copy number was calculated with BioRad CFX Manager 3.1. PCR amplification of the coding regions of Actb and Rplp0 was used for normalization. The data from at least 6 samples were analyzed, compared, plotted and expressed as a fold change in treated samples compared to controls.

\section{Statistical analysis}

The statistical tests were carried out using R software (R Core Team 2018). For each experiment, the results were separated and compared by modality. First, the data were tested for normality by the Shapiro test and homoscedasticity by the Bartlett test. If the data distribution for each 
modality followed a normal distribution and if the variances were equal, the Anova test was performed, a parametric comparison test. If the data of at least one of the groups was not normally distributed or if the data of the groups was distributed normally but the variances were not equal, the Kruskal-Wallis test was carried out, a non-parametric comparison test of average. The differences were considered statistically significant when $\mathrm{p}<0.05$. In this case, post-hoc tests were performed as follows: Tukey test after the Anova test and Mann-Whitney test after the Kruskal-Wallis test. At 5 d.o., 20 d.o. and 8 m.o., data was collected by randomizing in view of origin litter and pups was used as the experiment unit for statistical analysis. At 35 d.o., corresponding to the first complete wave of spermatogenesis, litters were used as the experiment unit for statistical analysis. 


\section{Results}

\section{Justification of the molecules and their doses used in the study}

In this study, we used both purified glyphosate and a commercial GBH, Roundup ${ }^{\circledR} 3$ Plus. We chose to add each of these compounds in drinking water from E10.5 until the last day of lactation (20dpp). We chose to start the treatment at E10.5, when primordial germ cells start to colonize the genital ridge. This developmental period allow us to specifically target the germ cells. To be relevant to human exposure, we treated pregnant mice with dose of $0.5 \mathrm{mg} / \mathrm{kg} / \mathrm{day}$, which corresponds to the acceptable daily intake (ADI) for glyphosate in Europe. In the United-States, the ADI is $1.75 \mathrm{mg} / \mathrm{kg} / \mathrm{day}$, which is about three times higher than the dose chosen in our study. We also tested the dose of $5 \mathrm{mg} / \mathrm{kg} /$ day, ten times less than the no-observed-adverse-effect-level (NOAEL) and the NOAEL dose, $50 \mathrm{mg} / \mathrm{kg} /$ day.

In our study, we analyzed seven experimental groups of males derived from pregnant mice treated with vehicle (called ctrl), glyphosate at the concentration of $0.5 \mathrm{mg} / \mathrm{kg} /$ day (called G0.5), $5 \mathrm{mg} / \mathrm{kg} /$ day (called G5) and $50 \mathrm{mg} / \mathrm{kg}$ /day (called G50) or with a GBH, the Roundup ${ }^{\circledR} 3$ Plus, at the concentration of $0.5 \mathrm{mg} / \mathrm{kg} /$ day (called R0.5), $5 \mathrm{mg} / \mathrm{kg} /$ day (called R5) and $50 \mathrm{mg} / \mathrm{kg} / \mathrm{day}$ (called R50).

\section{Perinatal exposure to glyphosate but not a GBH affects testis weight, the morphology of the seminiferous epithelium and the level of circulating testosterone at short term}

To analyze the effect of glyphosate and a GBH on spermatogenesis, we analyzed the effects of these compounds on body and organs weight and on the morphology of the testis. We did not 
observe any variations in body weight in 5 days-old (d.o.) and 35 d.o. animals, but we found an increase in body weight in 20 d.o. mice in G0.5 and R5 groups compared to control (suppl. Figure 1). In 20 d.o. mice, relative testis weight did not change in all groups except for the R50 treated group (data not shown). As production of spermatozoa takes about 35 days in mice, we chose this time point to consider the effect of glyphosate and GBH on a complete round of spermatogenesis. In 35 d.o. mice, no change of body weight was observed but a decrease in relative testis weight was observed in G0.5 and G5 groups compared to control (Figure 1A, B). In GBH group, the relative testis weight was not affected in 35 d.o. animals. We also checked the epididymis and seminal vesicle weights of 35 d.o. males of treated and control groups. A decrease in epididymis weight was observed in R0.5 group, and a decrease in seminal vesicle weights was detected in G5, G50 and R0.5 groups compared to the control group (Figure 1B-D).

To reveal whether exposure to glyphosate and a GBH leads to changes in spermatozoa numbers, we counted the spermatozoa in total epididymis of 35 d.o. males exposed to toxicant during gestation. We found a significant decrease of $89 \%$ and $84 \%$ spermatozoa numbers in G5 and R0.5 groups, respectively (Figure 1E). To assess the endocrine function following treatment, we measured testosteronemia. We determined that serum testosterone levels were about three times lower in G0.5 and G50 groups compared to the control group (Figure 1F). We considered at this time point the animals from the same litter as one biological replicate. We also checked that considered pups as experimental unit for statistical analysis does not change most of our result, meaning that origin litter does not affect our findings (data not shown). Our data showed that glyphosate alone affected the relative testis weight and led to a decrease in the levels of circulating testosterone. However, no change was observed in groups exposed to GBH. In addition, exposure to glyphosate and GBH lead to changes in relative seminal vesicle weights in 
G5, G50, R0.5 and R50 groups and affected the production of spermatozoa in G5 and R0.5 groups.

To determine whether exposure to glyphosate and a GBH could affect the cellular morphology, we prepared paraffin sections from exposed and control testes and performed an H\&E staining. The analysis of testis sections revealed that glyphosate causes an adverse effect on testis morphology in 20 d.o. males compared to the control (Figure 2A, E). In GBH groups, we did not observe changes in testis morphology, except for the presence of rare vacuoles in R5 group (Figure 2B-D). In glyphosate treated groups, an increase in vacuoles in the seminiferous epithelium was observed in G0.5, G5 and G50 groups (Figure 2F-H). In G5 group, some tubules were completely empty with a total absence of germ cell populations (Figure 2G). These effects were reversible, because in 35 d.o. glyphosate-treated animals, we did not observe the presence of vacuoles and testes looked normal (Figure 2I-L).

In summary, our data showed that exposure to a GBH had effects on seminal vesicles weight and spermatozoa numbers but only at some doses. Remarkably, in glyphosate-exposed groups, we observed changes in testis and seminal vesicles weights, spermatozoa numbers, testosterone levels and testis morphology, suggesting that the reproductive system was impaired by glyphosate itself.

\section{Perinatal exposure to glyphosate affects the number of undifferentiated spermatogonia in}

\section{5 d.o. adult mice}

As glyphosate treatment during gestation and lactation affected the testis morphology of 20 d.o. males and the testis weights and spermatozoa production in 35 d.o. mice, we investigated the effects of glyphosate alone on the number of undifferentiated spematogonia and Sertoli cells in 
35 d.o. mice. We immunostained testis sections using antibodies against proteins specific to these cell types (i.e., ZBTB16 and GATA1, respectively, (Figure 3A-B). Following quantification, we observed that glyphosate did not affect the number of GATA1 positive cells (Figure 3C) but induced a decrease in the number of ZBTB16 positive cells in G5 group in 35 d.o. animals (Figure 3D). This result indicates that glyphosate decreases the number of undifferentiated spermatogonia at this dose.

\section{Perinatal exposure to glyphosate affects spermatogonia differentiation during the first wave of spermatogenesis in mouse}

As glyphosate treatment during gestation and breastfeeding affected the number of undifferentiated spermatogonia in adults, we investigated the effects of this compound on undifferentiated prepubertal spermatogonia in 5 d.o. testis in glyphosate groups. At this time, Aal spermatogonia, which retain stem cell properties, have not yet differentiated into A1 spermatogonia, which are irreversibly committed toward gamete production. To this end, we counted the germ cells numbers in 5 d.o. testis by immunostaining the testis sections against the germ cell marker, DDX4 (also known as MVH) (Figure 4). We observed that the number of undifferentiated spermatogonia did not change in glyphosate-treated groups compared to the control (Figure 4A-C).

To reveal the effects of exposure on gene expression in spermatogonia, we performed quantitative, real-time PCR (RT-QPCR). For the analysis we chose genes encoding proteins involved in stem cell maintenance (Pou5f1, Foxol, Gfral, Nanos3, Ret, Zbtb16), germ cell differentiation (Sall4, Dazl, Sohlh1, Sohlh2, Kit), steroidogenesis (Cyp11A1, Cyp19A1), endocrine signalling (Fshr, Lhr, Esrl, Esr2, Star) and apoptosis (Bax, Bcl2). Our results showed that exposure to glyphosate did not affect the expression of genes implicated in steroidogenesis (Cyp11A1, Cyp19A1, Star) and genes implicated in estrogen signaling pathway (Fshr, Lhr, Esr l, 
Esr2, Star) (Figure 4 and Suppl. Figure 2). By contrast, glyphosate exposure leads to increased expression of Bax and Bcl2, which are genes involved in apoptosis (Figure 4D). Glyphosate treatment did not affect the expression of Sohlh1 but induced an increase in Dazl and Sohlh2 expression in group G0.5. Moreover, exposure to glyphosate led to a decrease in Kit expression in G50 group and in Sall4 expression in all glyphosate groups compared to control (Figure 4 and Suppl. Figure 2). Glyphosate also induced a non-significant increase ( $\mathrm{p}=0.06635)$ of Ret in G5 group, a significant increase of Nanos3 in G0.5 and G50 groups and of Foxol gene expression in G0.5 group compared to the control. Our results show that glyphosate alone promotes a decrease or an increase in the expression of genes involved in differentiation and an increase in genes involved in stem cell fate.

\section{Perinatal exposure to GBH affects long term testis weight and the circulating testosterone} levels

Since some chemicals do not have a clear short term effects but may have harmful effects in long term, the reproductive function of 8 months-old (m.o.) male offspring was examined. No changes in body weights were observed (data not shown). A decrease in relative testis weights were observed in G0.5 group, which correlates with the results of body weights in 35 d.o., and R5 groups (Figure 5A). No changes in the epididymis and seminal vesicle weights were observed (Figure 5B-C). The testosterone levels were dramatically reduced in R5 and R50 -by 90\% and $85 \%$ respectively but not in glyphosate groups (Figure 5D).

To reveal whether the reduction of testosterone level leads to changes in spermatozoa numbers, we also counted the spermatozoa in epididymis, but did not observe any significant changes (data not shown). The $H \& E$ morphologic analysis showed that there were no apparent 
differences between control and treated groups in 8 m.o. male offspring (Figure 5E), suggesting that the effects were reversible in the long term. Undifferentiated spermatogonia and Sertoli cell counts showed that there were no significant differences between control and treated groups (data not shown).

In summary, our results showed that glyphosate has low toxicity in male reproduction in the long term. In contrast, GBH decreases testosterone levels and testis weights in adult male mice eight months after exposure. 


\section{Discussion}

\section{Glyphosate and a GBH affect the reproductive function in males}

The aim of our study was to investigate the possible impact of glyphosate and a GBH (Roundup ${ }^{\circledR}$ 3 Plus) on the reproductive system of male mice. Most of the previous studies reported the effects of glyphosate either alone or as GBH. In our study, we tested pure glyphosate as well as its commercial preparation. Contrarly to the idea that the toxicity of the GBHs comes from the surfactants and adjuvants added in the formula (Tsui and Chu 2003; Mesnage et al. 2013; Johansson et al. 2018), we observed that glyphosate itself has stronger toxic effects on the reproductive system compared to $\mathrm{GBH}$ in the short term. Of note, however, it cannot be excluded that the difference in solubility between pure glyphosate (glyphosate acid) and glyphosate isopropylamine salt present in the GBH can also be responsible for the difference in toxicity observed. In fact, while glyphosate acid is moderately soluble in water (10 to $12 \mathrm{~g} / \mathrm{l})$, in contrast, the isopropylamine salt is very soluble in water $(1050 \mathrm{~g} / \mathrm{l})$ (INRS-Institut National de Recherche et de Sécurité 2009), suggesting the toxicokinetics of these two compounds are different. The glyphosate isopropylamine salt may have less toxicity than glyphosate acid because it can be excreted by the urinary tract more easily and quickly. However, more study will be needed to thoughtfully understand why at low dose and at short term, pure glyphosate shows more toxic effects in male reproduction than the GBH tested.

GBHs are produced by several companies (Monsanto, Bayer, Dow, Syngenta ...) and the mix of chemicals in each product differs from company to company. Therefore, it is difficult to predict 
the toxicity of all GBHs based only on one formula, especially for herbicides used for glyphosate-resistant plants, which contain other active substances.

Glyphosate did not have any effect on the body weight of animals tested in this study. These results are in consistent with the previous studies (Benachour et al. 2007; Dai et al. 2016) and indicate that the doses used in our study have no significant toxic effects on animals. The decrease in testicular weights observed in the G0.5 and G5 groups at 35 d.o. and G0.5 group at 8 m.o. indicates that glyphosate, even at low doses, can significantly impair spermatogenesis, as testicular weight is a very reliable indicator of the normal function of male reproductive system. Exposure to glyphosate and Roundup ${ }^{\circledR} 3$ Plus leads to a decrease in the weight of seminal vesicles at some doses. As the weight of seminal vesicles is directly influenced by androgens, our data shows that these two compounds have some endocrine disruptor activities. This fact was confirmed by measuring the level of testosterone in plasma after glyphosate exposure. In our study, the serum testosterone levels were significantly decreased in G0.5 and G50 groups at 35 d.o. and in R5 and R50 groups at 8 m.o. The decrease in testosterone level after exposure to Roundup ${ }^{\circledR}$ has been observed in previous studies (Dallegrave et al. 2007; Romano et al. 2010) but not with glyphosate alone. In 8 m.o. mice, the decrease in testosterone production in R5 and R50 groups is not associated with a decrease in seminal vesicles weight. In 35 d.o. mouse, this organ is significantly affected in R0.5 group. As in aged rodents the seminal vesicles may become very large (Knoblaugh et al. 2018), we suggest that the decrease in testosterone in these animals is not strong to cause the decrease in seminal vesicles size.

Moreover, the treatment with different doses of glyphosate or GHB didn't produce monotonic dose-responses. It is the case for data of epididymis and seminal vehicles weights, testosterone levels and spermatozoa counts in 35 d.o. animals. We observed here nonmonotonic dose- 
responses curve starting from a low concentration, the ADI, to the NOAEL. Recent findings showed that nonmonotonicity commonly occurs after exposure to endocrine-disrupting chemicals (EDC), as well as when animals are exposed to low dose. The effects are explained by the fact that the endocrine system responds to even very low concentration of hormones (Vandenberg et al. 2012). As nonmonotonicity involved different mechanisms as cytotoxicity, tissue-specific factors, receptor desensibilization among others (Vandenberg et al. 2012), it is conceivable that there is low correlation between different doses and observed effects on measured parameters.

The decrease in testosterone level after exposure to Roundup ${ }^{\circledR}$ has been observed in previous studies (Romano et al. 2010, Dallegrave et al. 2007) but not with glyphosate alone. As glyphosate didn't affect the expression of the Cyp19al transcript here, we suggest that the decrease could not be explained by the alteration of the activity of the aromatase enzyme, encoded by Cyp19al, which transforms testosterone into estradiol. However, in studies using human placental and embryonic cells it has been shown that the treatment with low concentrations of GBHs leads to changes in aromatase activity and mRNA level (Richard et al. 2005; Benachour et al. 2007). The toxicity of glyphosate may be mediated via its effects on endocrine regulation of the hypothalamic-pituitary axis (Yousef et al. 1995). On the other hand, Uren Webster et al. hypothesized that glyphosate disrupts the steroid biosynthetic pathway by causing oxidative stress (Uren Webster et al. 2014).

We observed that glyphosate or Roundup ${ }^{\circledR} 3$ Plus exposure led to a significant decrease in the spermatozoa numbers R0.5 groups at 35 days leading to a decrease of epididymis weights. This decrease in the spermatozoa numbers demonstrates that exposure to glyphosate or a GBH could reduce male fertility. The disturbance of the male reproductive function can also be observed if there are changes in testicular morphology. In rats, exposure to Roundup ${ }^{\circledR}$ can provoke the 
appearance of vacuoles and the degeneration of the seminiferous epithelium (Dallegrave et al. 2007); there are also changes in the epithelial height and luminal diameter of seminiferous tubules (Romano et al. 2010, Romano et al. 2012). In our study, the presence of vacuoles or absence of epithelium layers were observed in 20 d.o. animals of glyphosate groups, but the testicular morphology in treated groups became normal again at the age of 35 days, and at 8 months, suggesting that the toxic effects of glyphosate in the short term are reversible after the end of exposure.

\section{The adverse effect of glyphosate on germ cell differentiation}

The toxicity of glyphosate could be explained by direct cytotoxic effects on spermatogenesis via effects on the autocrine and paracrine regulatory pathways, emanating respectively from germ cells and Sertoli cells.

The first wave of spermatogenesis is accompanied by massive apoptosis in the testes, which mainly affects the pachytene spermatocytes (Jahnukainen et al. 2004). This cells death is considered to be important to obtain normal proportions between Sertoli cells and germ cells, which in turn, is essential for the differentiation and constitution of seminiferous tubules (Jahnukainen et al. 2004). The observed changes in the expression of key apoptosis genes (Bax, Bcl2) in glyphosate groups in our study could influence the balance between Sertoli cells and spermatogonia.

In G5 group (Figure 3D), we observed a decrease in spermatogonia number in 35 d.o. animals. As the cell count of the pool of undifferentiated spermatogonia in the testes of 5 d.o. animals confirmed that there were no changes in the number of germ cells in the glyphosate groups, the decrease in spermatogonia number in 35 d.o. animals may be the result of a modification of key 
genes involved in germ cell differentiation. In our study, we found dramatic changes in Sall4 and Kit mRNA expression in 5 d.o animals of glyphosate groups (Figure 4D). Both of these factors are part of the retinoic acid (RA) -dependent signaling pathway involved in the differentiation of Aal spermatogonia into $A 1$ which are irreversibly committed in the differentiation process (Busada et al. 2015; Gely-Pernot et al. 2015). This result suggests that glyphosate is able to alters spermatogonial differentiation and maturation and this explains, at least in part, the molecular mechanism responsible for the morphological defects observed in 20 d.o. males and the decrease in spermatozoa number observed in adults. It also shows that the RA-signaling pathway could be implicated in spermatogonia decline in the G50 group. Perinatal glyphosate treatment also increases mRNA expression of Ret, Nanos3 and Foxol, three factors involved in spermatogonia stem cell maintenance and self-renewal (Jijiwa et al. 2008; Lolicato et al. 2008: 3; Goertz et al. 2011: 1). This confirms the adverse effect of glyphosate on stem cell differentiation.

As deregulation of Sall4 and Kit expression can result in testicular cancer (Coffey et al. 2008; Cao et al. 2009) and as glyphosate is classified as a "probable carcinogen for humans" by the WHO (Guyton et al. 2015), it will be interesting to investigate a possible link between glyphosate or GBH exposure and testis cancer development in humans.

\section{Glyphosate and public health}

Several studies have reported a decrease in quantity and quality of sperm and an increase of male reproductive problems such as hypospadias and cryptorchidism over the last 50 years (Carlsen et al. 1992; Auger et al. 1995; Serrano et al. 2013; Levine et al. 2017). This problem could arise due to a possible impact of environmental factors such as agricultural products (Serrano et al. 2013; Köhn and Schuppe 2016). Among them, glyphosate is the most used herbicides in human history 
and actually is a huge question about its toxicity and its authorization for scientists as well as legislative authorities (Myers et al. 2016; Torretta et al. 2018). The use of glyphosate causes a global contamination not only in the soil, the surface and underground waters, and the atmosphere, but also in human and animal foods and objects of common use, such as diapers, medical gauze, and feminine hygiene products (Torretta et al. 2018; Zhao et al. 2018). In food and beverage contamination, glyphosate residues was found in cereals-based products (Liao et al. 2018), both conventional and organic honeys (Rubio et al. 2013), in legumes (Çetin et al. 2017), in beer (Jansons et al. 2018) and wine and fruit juice (Zoller et al. 2018). Glyphosate was then detectable in human milk (Torretta et al. 2018) and urine (Conrad et al. 2017; Connolly et al. 2018). Due to the large human population exposure to glyphosate, concerns have increased worldwide about its potential health effects. More studies are needed to understand whether glyphosate is toxic for human and if the actual ADI is safe for populations. Here, our study was not only to investigate the effects of glyphosate on the biology of male reproduction, but also to provide important scientific evidence of glyphosate toxicity to protect human health against its adverse effects.

\section{Conclusions}

Our research demonstrates that both glyphosate and a GBH affect the male reproductive system at low dose in mice. More precisely, perinatal exposure to glyphosate is reprotoxic to young animals, contrary to GBH exposure which is less toxic in the short term but shows its effect in the long term in testosterone levels and testis weight. At the ADI dose, our study shows that glyphosate could have endocrine disrupting effects which could impair male reproductive system. All these data together may help risk assessors reevaluate the glyphosate ADI to ensure the security of humans and ecosystems. 


\section{Table 1}

Primers used for quantitative RT-PCR

\begin{tabular}{|c|c|c|}
\hline $\begin{array}{l}\text { Gene } \\
\text { symbol }\end{array}$ & 5' - 3' forward primers & 5' - 3’ reverse primers \\
\hline$\overline{A c t b}$ & 5'-CCAACTGGGACGACATGGAG-3' & 5'-ACAGCACAGCCTGGATGGC-3' \\
\hline Foxol & 5'-ATCACCAAGGCCATCGAGAG-3' & 5'-GTGAAGGGACAGATTGTGGC-3' \\
\hline Nanos3 & 5'-CGGCCTGACAAGGCAAAGAC-3' & 5'-CACCATGGTCCTCCCCACTC-3' \\
\hline Ret & 5'-TGGGCTCCCGAGATGTTT-3' & 5'-TTGCCTCCCAGGGTCACAAT-3' \\
\hline Gfral & 5'-CAACTTCAGCCTGACATCCG-3' & 5'-CCGCTCATATGGGGAATCT-3' \\
\hline Zbtb16 & 5'-AACGGTTCCTGGACAGTTTG-3' & 5'-CCCACAGCAGACAGAAGA-3' \\
\hline Kit & 5'-AGCGTCTTCCGGCACAACGG-3' & 5'-GCCAATGAGCAGCGGCGTGA-3' \\
\hline Stra8 & $\begin{array}{l}\text { 5'- } \\
\text { GATGCTTTTGACGTGGCAAGTTTCC-3' }\end{array}$ & 5'-TCATCATCTGGGGGCTCTGGTTC-3' \\
\hline Sohlh1 & 5'-GGGCCAATGAGGATTACAGA-3' & 5'-CACAGGAGCTGTGCAGAGAG-3' \\
\hline Sohlh2 & 5'-TCAGTGAGCCGCTGACCTTG-3' & 5'-AAAAACGCCCTCCGAGTTCAC-3' \\
\hline Dazl & 5'-CAGTATGTTCAGGCATATCCTC-3' & 5'-ATTCATTGGGCAAAATATCAGC-3' \\
\hline Star & 5’-TCTCTGCTTGGTTCTCAACT-3' & 5'-AAACACCTTGCCCACATCTG-3' \\
\hline Sall4 & 5'-GAGCGAACACACACGGGAGA-3' & 5'-GCGCTCTCTTTCCCTGAGCA-3' \\
\hline Fshr & 5'-GTCTGTGCCAGTGACAATGCC-3' & 5'-TTCCTCCGTTTCTTCCGAGATG-3' \\
\hline Lhr & 5'-TGCCTTTGACAACCТCCТCA-3' & 5'-TCGAAACATCTGGGAGGGTC-3' \\
\hline Cyp19a1 & 5'-TCGGCATGCATGAGAACGGC-3' & 5'-TTCGCCCAGCCGGTCCAAAT-3' \\
\hline Cypllal & 5'-ACACGACCTCCATGACCCTGC-3' & 5'-GCAAGGTCACGGAGATGGGGT-3' \\
\hline Bax & 5'-TTTGCTACAGGGTTTCATCCAG-3' & 5'-CCAGTTCATCTCCAATTCGCC-3' \\
\hline
\end{tabular}




\begin{tabular}{lll}
\hline Bcl 2 & 5'-GTGtGGAGAGCGTCAACAGG-3' & 5'-CACAAAGGCATCCCAGCCTC \\
Ddx4 5'-ACAGGATGTCCCCGCATGGC-3' & 5'-TCCCATGACTCGTCATCAACTGGA-3' \\
Pou5f1 5'-AGACCACCATCTGTCGCTTC-3' & 5'-ATCCTTCTCTAGCCCAAGCTG-3' \\
\hline
\end{tabular}




\section{Supplemental data}

The TEMPORARY REVIEW LINK is:

https://datadryad.org/review?doi=doi:10.5061/dryad.4319rp6

(for journal access prior to manuscript acceptance only. Include with your submitted manuscript but NOT in the final proofs)

The DRYAD DOI is:

doi:10.5061/dryad.4319rp6

(for inclusion in the published article) 


\section{Figure legends}

Figure 1: Perinatal exposure to glyphosate and/or GBH affects testis, epididymis and seminal vesicles weight, the number of spermatozoa and the secretion of testosterone in 35 d.o. mice. (A) Body weight and (B) testis, (C) epididymis and (D) seminal vesicle weight in 35 d.o. mice derived from females treated with vehicle (Ctrl; in grey), glyphosate (G0.5, G5, G50; in bleu) and a GBH (R0.5, R5, R50; in green). (E) Spermatozoa number in epididymis. (F) The amount of testosterone levels in serum decreased in G0.5 and G50 groups compared to control. Values are expressed as mean value \pm standard error. Ctrl, G0.5, G50, R0.5, R5: $\mathrm{n}=4$ litters (with 6 pups by litters); G5, R50: $\mathrm{n}=3$ litters (with 5 and 7 pups by litters respectively). Statistical analyses were performed on the n number of litters using Kruskal-Wallis test followed by MannWhitney post-hoc test to compare the control and treated groups, ${ }^{*} \mathrm{p}<0.05$, is considered to be significantly different from the control group.

Figure 2: Perinatal exposure to glyphosate and not to a GBH affects the testis morphology in 20 d.o. mice. H\&E staining of the histological sections in (A-H) 20 and (I-L) 35 d.o. mice from (A, E and I) ctrl, (B) R0.5, (C) R5, (D) R50, (F;J) G0.5, (G;K) G5 and (H;L) G50, experimental groups. An increase in vacuoles in the seminiferous epithelium of the testis (arrow) and empty tubules (star) were observed in glyphosate group (G0.5, G5 and G50) compared to control. The presence of vacuoles were observed in R5 group as well. In 20 d.o. mice, $\mathrm{n}=5$ for each conditions, in 35 d.o. mice, Ctrl, R0.5, R5, R50, G0.5: n=6; G5: n=5; G50: $n=7$ 
Figure 3: Perinatal exposure to glyphosate decreases the number of undifferentiated spermatogonia in adult mice. Representative images of testes sections from (A) the control (left panel) and (B) glyphosate (G5; right panel) animals: Sertoli cells and spermatogonia (Spg) were immunostained using anti-GATA1 (red) or anti-ZBTB16 (green) antibodies, respectively. The ZBTB16 antibody staining of Leydig cells located outside of seminiferous tubules is nonspecific. A quantitative analysis of (C) Sertoli cells and (D) spermatogonia was performed by manually counting the GATA1 and ZBTB16 positive cells at stage VII of the seminiferous epithelium. The contour of each tubule section was measured using ImageJ. The values shown indicate the cell counts per micrometre of tubule circumference. Values are mean \pm standard error; $\mathrm{n}=5$ for all conditions. Statistical analyses were performed on the $\mathrm{n}$ number of progeny using Kruskal-Wallis test followed by Mann-Whitney post-hoc test to compare the control and treated groups. $* \mathrm{p}<0.05, * * \mathrm{p}<0.01$ are considered to be significantly different compared to the control group. Scale bar $150 \mu \mathrm{m}$. The immunostaining of the testis sections was performed as described in the Methods section.

Figure 4: Perinatal exposure to glyphosate affects the expression of the genes involved in spermatogonia differentiation in prepubertal 5 d.o. mice. Representative images of testes sections from (A) the control (left panel) and (B) glyphosate (G5; right panel) animals:

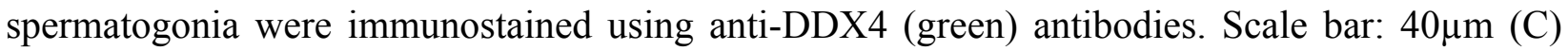
Quantitative analysis of the number of spermatogonia showed no any significant differences in 5 d.o. testis. (D) RT-QPCR analysis of RNA expression in control (Ctrl; in grey) and glyphosate groups (G0.5, G5, G50; in bleu). Values are mean \pm standard error. Ctrl, G5, G50: n =6; G0.5: $\mathrm{n}=7$. Statistical analyses were performed on the n number of progeny using Kruskal-Wallis test followed by Mann-Whitney post-hoc test to compare the control and a treated groups. ${ }^{*} p<0.05$, 
** $\mathrm{p}<0.01$ are considered to be significantly different compared to control. The copy numbers of each target gene were normalized to Actb and Rplp0. Data were presented as normalized values compared to control.

Figure 5: Perinatal exposure to glyphosate and a GBH affects the testis weight and exposure to GBH but not to glyphosate decreases serum testosterone levels in 8 m.o. mice. (A) Testis, (B) epididymis and (C) seminal vesicle weights in 8 m.o. mice derived from females treated with vehicle (ctrl; in grey), glyphosate ( G0.5, G5, G50; in bleu) and a GBH (R0.5, R5, R50; in green). Ctrl: $n=6 ; G 0.5: n=13 ; G 5: n=20 ; G 50: n=10 ; R 0.5: n=12 ; R 5: n=6 ; R 50: n=8$ (D). The amount of testosterone level in serum were decreased in R5 and R50 groups compared to control. Values are mean \pm standard error; Ctrl: $n=12$; G0.5: $n=13$; G5: $n=20 ; G 50: n=10$; R0.5: $n=12 ; R 5: n=6 ; R 50: n=7$. Statistical analyses were performed on the $n$ number of progeny using Kruskal-Wallis test followed by Mann-Whitney post-hoc test to compare the control group with a treated group. ${ }^{*} \mathrm{p}<0.05,{ }^{*} \mathrm{p}<0.01$ are considered to be significantly different compared to control. (E) H\&E staining of the histological sections in 8 m.o. mice from ctrl and R50 experimental groups. Scale bar: $100 \mu \mathrm{m}$.

\section{Suppl Figure 1: Perinatal exposure to glyphosate and a GBH does not affect body weight in} mice. Body weight of (A) 5, (B) 20 d.o. an 35 d.o. mice derived from control (Ctrl in grey), glyphosate (G0.5, G5, G50 in blue) and a GBH (R0.5, R5, R50 in green)-treated pregnant female mice. A small increase in body weight was observed in G0.5 and R5 treated 20 d.o mice when compared to the control. Values are mean \pm standard error. In 5 d.o. mice, Ctrl, G5, G50, R0.5, R5, R50: $n=6$; G0.5: $n=7$. In 20 d.o. mice, $n=5$ for each conditions. Statistical analyses were performed on the n number of progeny using Kruskal-Wallis test followed by Mann-Whitney 
post-hoc test to compare the control group with a treated group. ${ }^{*} p<0.05$ is considered to be a significantly different compared to control.

\section{Suppl Figure 2: Perinatal exposure to glyphosate does not affect the expression of genes} involved in endocrine-signaling pathway in 5 d.o. prepubertal mice. RT-QPCR analysis of RNA expression in control (Ctrl; in grey) and glyphosate groups (G0.5, G5, G50; in blue). Values are mean \pm standard error. Ctrl, G5, G50: $n=6 ;$ G0.5: $n=7$. Statistical analyses were performed on the $\mathrm{n}$ number of progeny using Kruskal-Wallis test followed by Mann-Whitney post-hoc test to compare the control group with a treated group. ${ }^{* *} \mathrm{p}<0.01$ significant difference from the control. The copy numbers of each target gene were normalised to Rplp0 and Actb and data were presented as normalised values compared to control.

\section{References}

Albert O, Jégou B. 2014. A critical assessment of the endocrine susceptibility of the human testis to phthalates from fetal life to adulthood. Hum Reprod Update. 20(2):231-249.

doi:10.1093/humupd/dmt050.

Andreotti G, Koutros S, Hofmann JN, Sandler DP, Lubin JH, Lynch CF, Lerro CC, De Roos AJ, Parks CG, Alavanja MC, et al. 2018. Glyphosate Use and Cancer Incidence in the Agricultural Health Study. J Natl Cancer Inst. 110(5):509-516. doi:10.1093/jnci/djx233.

de Araujo JSA, Delgado IF, Paumgartten FJR. 2016. Glyphosate and adverse pregnancy outcomes, a systematic review of observational studies. BMC Public Health. 16:472. doi:10.1186/s12889-016-3153-3.

Auger J, Kunstmann JM, Czyglik F, Jouannet P. 1995. Decline in semen quality among fertile men in Paris during the past 20 years. N Engl J Med. 332(5):281-285.

doi:10.1056/NEJM199502023320501. 
Benachour N, Sipahutar H, Moslemi S, Gasnier C, Travert C, Séralini GE. 2007. Time- and dosedependent effects of roundup on human embryonic and placental cells. Arch Environ Contam Toxicol. 53(1):126-133. doi:10.1007/s00244-006-0154-8.

Benbrook CM. 2016. Trends in glyphosate herbicide use in the United States and globally. Environ Sci Eur. 28(1). doi:10.1186/s12302-016-0070-0. [accessed 2018 Jul 17]. https://www.ncbi.nlm.nih.gov/pmc/articles/PMC5044953/.

Busada JT, Chappell VA, Niedenberger BA, Kaye EP, Keiper BD, Hogarth CA, Geyer CB. 2015. Retinoic acid regulates Kit translation during spermatogonial differentiation in the mouse. Dev Biol. 397(1):140-149. doi:10.1016/j.ydbio.2014.10.020.

Cao D, Li J, Guo CC, Allan RW, Humphrey PA. 2009. SALL4 is a novel diagnostic marker for testicular germ cell tumors. Am J Surg Pathol. 33(7):1065-1077.

doi:10.1097/PAS.0b013e3181a13eef.

Carlsen E, Giwercman A, Keiding N, Skakkebaek NE. 1992. Evidence for decreasing quality of semen during past 50 years. BMJ. 305(6854):609-613.

Çetin E, Şahan S, Ülgen A, Şahin U. 2017. DLLME-spectrophotometric determination of glyphosate residue in legumes. Food Chem. 230:567-571. doi:10.1016/j.foodchem.2017.03.063.

Coffey J, Linger R, Pugh J, Dudakia D, Sokal M, Easton DF, Timothy Bishop D, Stratton M, Huddart R, Rapley EA. 2008. Somatic KIT mutations occur predominantly in seminoma germ cell tumors and are not predictive of bilateral disease: report of 220 tumors and review of literature. Genes Chromosomes Cancer. 47(1):34-42. doi:10.1002/gcc.20503.

Connolly A, Jones K, Galea KS, Basinas I, Kenny L, McGowan P, Coggins M. 2017. Exposure assessment using human biomonitoring for glyphosate and fluroxypyr users in amenity horticulture. Int J Hyg Environ Health. 220(6):1064-1073. doi:10.1016/j.ijheh.2017.06.008.

Connolly A, Leahy M, Jones K, Kenny L, Coggins MA. 2018. Glyphosate in Irish adults - A pilot study in 2017. Environ Res. 165:235-236. doi:10.1016/j.envres.2018.04.025.

Conrad A, Schröter-Kermani C, Hoppe H-W, Rüther M, Pieper S, Kolossa-Gehring M. 2017. Glyphosate in German adults - Time trend (2001 to 2015) of human exposure to a widely used herbicide. Int J Hyg Environ Health. 220(1):8-16. doi:10.1016/j.ijheh.2016.09.016.

Dai P, Hu P, Tang J, Li Y, Li C. 2016. Effect of glyphosate on reproductive organs in male rat. Acta Histochem. 118(5):519-526. doi:10.1016/j.acthis.2016.05.009.

Dallegrave E, Mantese FD, Oliveira RT, Andrade AJM, Dalsenter PR, Langeloh A. 2007. Preand postnatal toxicity of the commercial glyphosate formulation in Wistar rats. Arch Toxicol. 81(9):665-673. doi:10.1007/s00204-006-0170-5.

Damalas CA, Eleftherohorinos IG. 2011. Pesticide Exposure, Safety Issues, and Risk Assessment Indicators. Int J Environ Res Public Health. 8(5):1402-1419. doi:10.3390/ijerph8051402. 
Duke SO, Powles SB. 2008. Glyphosate: a once-in-a-century herbicide. Pest Manag Sci. 64(4):319-325. doi:10.1002/ps.1518.

European Food Safety Authority (EFSA). 2015. Conclusion on the peer review of the pesticide risk assessment of the active substance glyphosate.

European Food Safety Authority (EFSA). 2017. Peer review of the pesticide risk assessment of the potential endocrine disrupting properties of glyphosate. EFSA J. 15(9).

doi:10.2903/j.efsa.2017.4979. [accessed 2018 Nov 8].

http://doi.wiley.com/10.2903/j.efsa.2017.4979.

Gely-Pernot A, Hao C, Legoff L, Multigner L, D’Cruz SC, Kervarrec C, Jégou B, Tevosian S, Smagulova F. 2018. Gestational exposure to chlordecone promotes transgenerational changes in the murine reproductive system of males. Sci Rep. 8(1):10274. doi:10.1038/s41598-018-28670w.

Gely-Pernot A, Raverdeau M, Teletin M, Vernet N, Féret B, Klopfenstein M, Dennefeld C, Davidson I, Benoit G, Mark M, et al. 2015. Retinoic Acid Receptors Control Spermatogonia Cell-Fate and Induce Expression of the SALL4A Transcription Factor. PLoS Genet. 11(10):e1005501. doi:10.1371/journal.pgen.1005501.

Goertz MJ, Wu Z, Gallardo TD, Hamra FK, Castrillon DH. 2011. Foxo1 is required in mouse spermatogonial stem cells for their maintenance and the initiation of spermatogenesis. J Clin Invest. 121(9):3456-3466. doi:10.1172/JCI57984.

Gonçalves BB, Nascimento NF, Santos MP, Bertolini RM, Yasui GS, Giaquinto PC. 2018. Low concentrations of glyphosate-based herbicide cause complete loss of sperm motility of yellowtail tetra fish Astyanax lacustris. J Fish Biol. 92(4):1218-1224. doi:10.1111/jfb.13571.

Guyton KZ, Loomis D, Grosse Y, El Ghissassi F, Benbrahim-Tallaa L, Guha N, Scoccianti C, Mattock H, Straif K, International Agency for Research on Cancer Monograph Working Group, IARC, Lyon, France. 2015. Carcinogenicity of tetrachlorvinphos, parathion, malathion, diazinon, and glyphosate. Lancet Oncol. 16(5):490-491. doi:10.1016/S1470-2045(15)70134-8.

INRS-Institut National de Recherche et de Sécurité. 2009. In: Base de donnée FICHES TOXICOLOGIQUES: Glyphosate, Fiche toxicologique no 273.

Jahnukainen K, Chrysis D, Hou M, Parvinen M, Eksborg S, Söder O. 2004. Increased apoptosis occurring during the first wave of spermatogenesis is stage-specific and primarily affects midpachytene spermatocytes in the rat testis. Biol Reprod. 70(2):290-296. doi:10.1095/biolreprod.103.018390.

Jansons M, Pugajeva I, Bartkevičs V. 2018. Occurrence of glyphosate in beer from the Latvian market. Food Addit Contam Part Chem Anal Control Expo Risk Assess. 35(9):1767-1775. doi:10.1080/19440049.2018.1469051. 
Jayasumana C, Gunatilake S, Siribaddana S. 2015. Simultaneous exposure to multiple heavy metals and glyphosate may contribute to Sri Lankan agricultural nephropathy. BMC Nephrol. 16(1):103. doi:10.1186/s12882-015-0109-2.

Jégou B. 1993. The Sertoli-germ cell communication network in mammals. Int Rev Cytol. 147:25-96.

Jenardhanan P, Panneerselvam M, Mathur PP. 2016. Effect of environmental contaminants on spermatogenesis. Semin Cell Dev Biol. 59:126-140. doi:10.1016/j.semcdb.2016.03.024.

Jijiwa M, Kawai K, Fukihara J, Nakamura A, Hasegawa M, Suzuki C, Sato T, Enomoto A, Asai N, Murakumo Y, et al. 2008. GDNF-mediated signaling via RET tyrosine 1062 is essential for maintenance of spermatogonial stem cells. Genes Cells Devoted Mol Cell Mech. 13(4):365-374. doi:10.1111/j.1365-2443.2008.01171.x.

Johansson HKL, Schwartz CL, Nielsen LN, Boberg J, Vinggaard AM, Bahl MI, Svingen T. 2018. Exposure to a glyphosate-based herbicide formulation, but not glyphosate alone, has only minor effects on adult rat testis. Reprod Toxicol Elmsford N. 82:25-31.

doi:10.1016/j.reprotox.2018.09.008.

Knoblaugh SE, True L, Tretiakova M, Hukkanen RR. 2018. 18 - Male Reproductive System. In: Treuting PM, Dintzis SM, Montine KS, editors. Comparative Anatomy and Histology (Second Edition). San Diego: Academic Press. p. 335-363. [accessed 2018 Dec 14]. http://www.sciencedirect.com/science/article/pii/B978012802900800018X.

Köhn F-M, Schuppe HC. 2016. [Environmental factors and male fertility]. Urol Ausg A. 55(7):877-882. doi:10.1007/s00120-016-0150-1.

Levine H, Jørgensen N, Martino-Andrade A, Mendiola J, Weksler-Derri D, Mindlis I, Pinotti R, Swan SH. 2017. Temporal trends in sperm count: a systematic review and meta-regression analysis. Hum Reprod Update. 23(6):646-659. doi:10.1093/humupd/dmx022.

Liao Y, Berthion J-M, Colet I, Merlo M, Nougadère A, Hu R. 2018. Validation and application of analytical method for glyphosate and glufosinate in foods by liquid chromatography-tandem mass spectrometry. J Chromatogr A. 1549:31-38. doi:10.1016/j.chroma.2018.03.036.

Lolicato F, Marino R, Paronetto MP, Pellegrini M, Dolci S, Geremia R, Grimaldi P. 2008. Potential role of Nanos3 in maintaining the undifferentiated spermatogonia population. Dev Biol. 313(2):725-738. doi:10.1016/j.ydbio.2007.11.011.

Lopes FM, Varela Junior AS, Corcini CD, da Silva AC, Guazzelli VG, Tavares G, da Rosa CE. 2014. Effect of glyphosate on the sperm quality of zebrafish Danio rerio. Aquat Toxicol Amst Neth. 155:322-326. doi:10.1016/j.aquatox.2014.07.006.

Mesnage R, Bernay B, Séralini G-E. 2013. Ethoxylated adjuvants of glyphosate-based herbicides are active principles of human cell toxicity. Toxicology. 313(2-3):122-128.

doi:10.1016/j.tox.2012.09.006. 
Mesnage R, Defarge N, Spiroux de Vendômois J, Séralini GE. 2015. Potential toxic effects of glyphosate and its commercial formulations below regulatory limits. Food Chem Toxicol Int $\mathbf{J}$ Publ Br Ind Biol Res Assoc. 84:133-153. doi:10.1016/j.fct.2015.08.012.

Myers JP, Antoniou MN, Blumberg B, Carroll L, Colborn T, Everett LG, Hansen M, Landrigan PJ, Lanphear BP, Mesnage R, et al. 2016. Concerns over use of glyphosate-based herbicides and risks associated with exposures: a consensus statement. Environ Health Glob Access Sci Source. 15:19. doi:10.1186/s12940-016-0117-0.

Owagboriaye FO, Dedeke GA, Ademolu KO, Olujimi OO, Ashidi JS, Adeyinka AA. 2017. Reproductive toxicity of Roundup herbicide exposure in male albino rat. Exp Toxicol Pathol Off J Ges Toxikol Pathol. 69(7):461-468. doi:10.1016/j.etp.2017.04.007.

Palanza P, Nagel SC, Parmigiani S, vom Saal FS. 2016. Perinatal exposure to endocrine disruptors: sex, timing and behavioral endpoints. Curr Opin Behav Sci. 7:69-75. doi:10.1016/j.cobeha.2015.11.017.

Panzacchi S, Mandrioli D, Manservisi F, Bua L, Falcioni L, Spinaci M, Galeati G, Dinelli G, Miglio R, Mantovani A, et al. 2018. The Ramazzini Institute 13-week study on glyphosate-based herbicides at human-equivalent dose in Sprague Dawley rats: study design and first in-life endpoints evaluation. Environ Health. 17(1). doi:10.1186/s12940-018-0393-y. [accessed 2018 Dec 14]. https://ehjournal.biomedcentral.com/articles/10.1186/s12940-018-0393-y.

Parvez S, Gerona RR, Proctor C, Friesen M, Ashby JL, Reiter JL, Lui Z, Winchester PD. 2018. Glyphosate exposure in pregnancy and shortened gestational length: a prospective Indiana birth cohort study. Environ Health. 17(1):23. doi:10.1186/s12940-018-0367-0.

Pryor JL, Hughes C, Foster W, Hales BF, Robaire B. 2000. Critical windows of exposure for children's health: the reproductive system in animals and humans. Environ Health Perspect. 108(Suppl 3):491-503.

Pubchem. Glyphosate. [accessed 2018 Nov 19]. https://pubchem.ncbi.nlm.nih.gov/compound/3496.

R Core Team. 2018. R: A Language and Environment for Statistical Computing. Vienna, Austria: R Foundation for Statistical Computing.

Raverdeau M, Gely-Pernot A, Féret B, Dennefeld C, Benoit G, Davidson I, Chambon P, Mark M, Ghyselinck NB. 2012. Retinoic acid induces Sertoli cell paracrine signals for spermatogonia differentiation but cell autonomously drives spermatocyte meiosis. Proc Natl Acad Sci U S A. 109(41):16582-16587. doi:10.1073/pnas.1214936109.

Richard S, Moslemi S, Sipahutar H, Benachour N, Seralini G-E. 2005. Differential effects of glyphosate and roundup on human placental cells and aromatase. Environ Health Perspect. 113(6):716-720.

Romano MA, Romano RM, Santos LD, Wisniewski P, Campos DA, de Souza PB, Viau P, Bernardi MM, Nunes MT, de Oliveira CA. 2012. Glyphosate impairs male offspring reproductive 
development by disrupting gonadotropin expression. Arch Toxicol. 86(4):663-673. doi:10.1007/s00204-011-0788-9.

Romano RM, Romano MA, Bernardi MM, Furtado PV, Oliveira CA. 2010. Prepubertal exposure to commercial formulation of the herbicide glyphosate alters testosterone levels and testicular morphology. Arch Toxicol. 84(4):309-317. doi:10.1007/s00204-009-0494-z.

Rubio F, Guo E, Kamp L. 2013. Survey of Glyphosate Residues in Honey, Corn and Soy Products. J Environ Anal Toxicol. 5(1):1-8. doi:10.4172/2161-0525.1000249.

Serrano T, Chevrier C, Multigner L, Cordier S, Jégou B. 2013. International geographic correlation study of the prevalence of disorders of male reproductive health. Hum Reprod Oxf Engl. 28(7):1974-1986. doi:10.1093/humrep/det111.

Solomon KR. 2016. Glyphosate in the general population and in applicators: a critical review of studies on exposures. Crit Rev Toxicol. 46(sup1):21-27. doi:10.1080/10408444.2016.1214678.

de Souza JS, Kizys MML, da Conceição RR, Glebocki G, Romano RM, Ortiga-Carvalho TM, Giannocco G, da Silva IDCG, Dias da Silva MR, Romano MA, et al. 2017. Perinatal exposure to glyphosate-based herbicide alters the thyrotrophic axis and causes thyroid hormone homeostasis imbalance in male rats. Toxicology. 377:25-37. doi:10.1016/j.tox.2016.11.005.

Steinrücken HC, Amrhein N. 1980. The herbicide glyphosate is a potent inhibitor of 5enolpyruvylshikimic acid-3-phosphate synthase. Biochem Biophys Res Commun. 94(4):12071212. doi:10.1016/0006-291X(80)90547-1.

Tarazona JV, Court-Marques D, Tiramani M, Reich H, Pfeil R, Istace F, Crivellente F. 2017. Glyphosate toxicity and carcinogenicity: a review of the scientific basis of the European Union assessment and its differences with IARC. Arch Toxicol. 91(8):2723-2743. doi:10.1007/s00204017-1962-5.

Tarone RE. 2018 Sep 5. Conflicts of interest, bias, and the IARC Monographs Program. Regul Toxicol Pharmacol. doi:10.1016/j.yrtph.2018.09.005. [accessed 2018 Oct 21]. http://www.sciencedirect.com/science/article/pii/S0273230018302277.

Torretta V, Katsoyiannis IA, Viotti P, Rada EC. 2018. Critical Review of the Effects of Glyphosate Exposure to the Environment and Humans through the Food Supply Chain. Sustainability. 10(4):950. doi:10.3390/su10040950.

Tsui MTK, Chu LM. 2003. Aquatic toxicity of glyphosate-based formulations: comparison between different organisms and the effects of environmental factors. Chemosphere. 52(7):11891197. doi:10.1016/S0045-6535(03)00306-0.

Uren Webster TM, Laing LV, Florance H, Santos EM. 2014. Effects of glyphosate and its formulation, roundup, on reproduction in zebrafish (Danio rerio). Environ Sci Technol. 48(2):1271-1279. doi:10.1021/es404258h. 
Vallet-Erdtmann V, Tavernier G, Contreras JA, Mairal A, Rieu C, Touzalin A-M, Holm C, Jégou B, Langin D. 2004. The testicular form of hormone-sensitive lipase HSLtes confers rescue of male infertility in HSL-deficient mice. J Biol Chem. 279(41):42875-42880.

doi:10.1074/jbc.M403495200.

Vandenberg LN, Colborn T, Hayes TB, Heindel JJ, Jacobs DR, Lee D-H, Shioda T, Soto AM, vom Saal FS, Welshons WV, et al. 2012. Hormones and endocrine-disrupting chemicals: lowdose effects and nonmonotonic dose responses. Endocr Rev. 33(3):378-455.

doi:10.1210/er.2011-1050.

Yousef MI, Salem MH, Ibrahim HZ, Helmi S, Seehy MA, Bertheussen K. 1995. Toxic effects of carbofuran and glyphosate on semen characteristics in rabbits. J Environ Sci Health B. 30(4):513-534. doi:10.1080/03601239509372951.

Zhao J, Pacenka S, Wu J, Richards BK, Steenhuis T, Simpson K, Hay AG. 2018. Detection of glyphosate residues in companion animal feeds. Environ Pollut Barking Essex 1987. 243(Pt B):1113-1118. doi:10.1016/j.envpol.2018.08.100.

Zoller O, Rhyn P, Rupp H, Zarn JA, Geiser C. 2018. Glyphosate residues in Swiss market foods: monitoring and risk evaluation. Food Addit Contam Part B Surveill. 11(2):83-91.

doi:10.1080/19393210.2017.1419509.

\section{Acknowledgements}

The authors would like to thank Nathalie Bonvallot for discussions around the doses used in this study and Shereen D'Cruz who helped correct the manuscript. We also thank Christele DesdoitsLethimonier for helping in serum testosterone measurements.

\section{Funding}

This work was supported by the Atip-Avenir program (R13139NS) from Institut national de la santé et de la recherché médicale (Inserm) to FS.

\section{Disclosure declaration}


The authors declare that they have no competing interests.

\section{Author contributions}

AGP designed the research. AGP, THP, PYK, CK performed the experiments. BJ and FS participated in the experimental design and contributed to the manuscript. THP, FS and AGP wrote the manuscript. All authors participated in editing the manuscript. All authors read and approved the final version of the manuscript. 
Figure 1
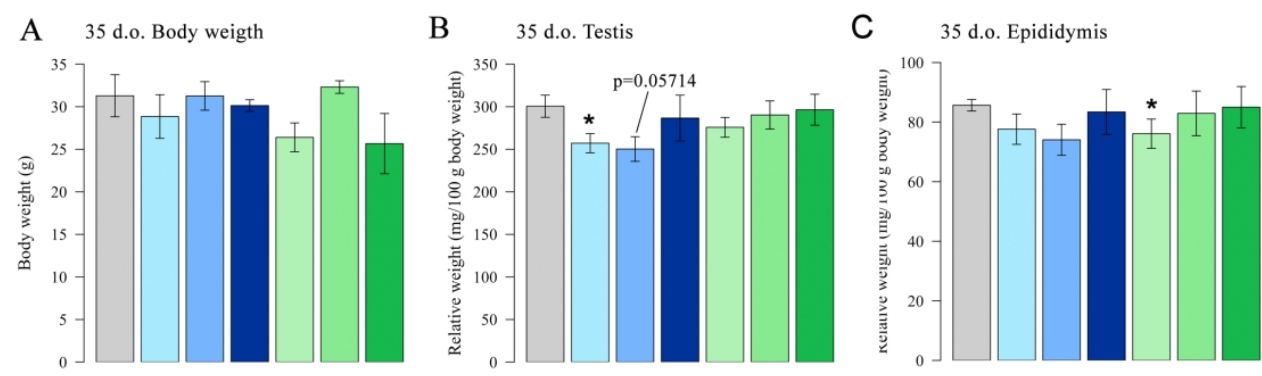

$\begin{array}{llllllll}\text { Ctrl } & \text { G0.5 } & \text { G5 } & \text { G50 } & \text { R0.5 } & \text { R5 } & \text { R50 }\end{array}$

$\begin{array}{llllllll}\text { Ctrl } & \text { G0.5 } & \text { G5 } & \text { G50 } & \text { R0.5 } & \text { R5 } & \text { R50 }\end{array}$

$\begin{array}{lllllll}\text { Ctrl } & \text { G0.5 } & \text { G5 } & \text { G50 } & \text { R0.5 } & \text { R5 } & \text { R50 }\end{array}$
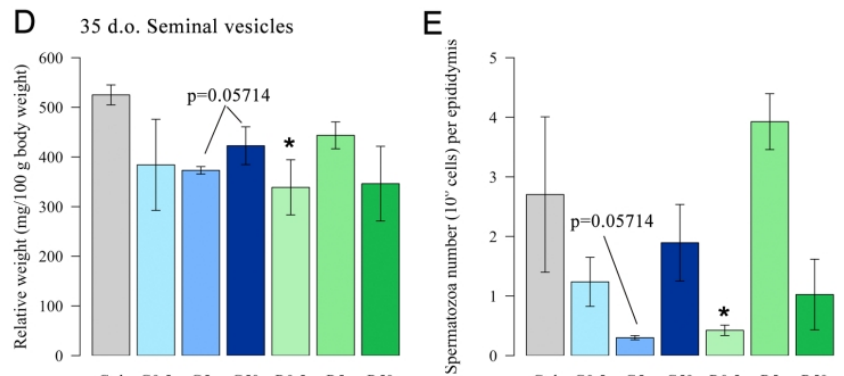

F

$\begin{array}{llllllll}\text { Ctrl } & \text { G0.5 } & \text { G5 } & \text { G50 } & \text { R0.5 } & \text { R5 } & \text { R50 }\end{array}$

$\begin{array}{lllllllll}\text { Ctrl } & \text { G0.5 } & \text { G5 } & \text { G50 } & \text { R0.5 } & \text { R5 } & \text { R50 }\end{array}$

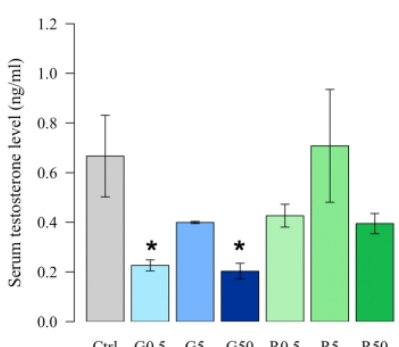

Figure 1: Perinatal exposure to glyphosate and/or GBH affects testis, epididymis and seminal vesicles weight, the number of spermatozoa and the secretion of testosterone in 35 d.o. mice. (A) Body weight and (B) testis, (C) epididymis and (D) seminal vesicle weight in 35 d.o. mice derived from females treated with vehicle (Ctrl; in grey), glyphosate (G0.5, G5, G50; in bleu) and a GBH (R0.5, R5, R50; in green). (E) Spermatozoa number in epididymis. (F) The amount of testosterone levels in serum decreased in G0.5 and G50 groups compared to control. Values are expressed as mean value \pm standard error. Ctrl, G0.5, G50, R0.5, R5: $n=4$ litters (with 6 pups by litters); G5, R50: $n=3$ litters (with 5 and 7 pups by litters respectively). Statistical analyses were performed on the $\mathrm{n}$ number of litters using Kruskal-Wallis test followed by Mann-Whitney post-hoc test to compare the control and treated groups, *p <0.05, is considered to be significantly different from the control group.

$199 \times 139 \mathrm{~mm}(300 \times 300 \mathrm{DPI})$ 


\section{Figure 2}

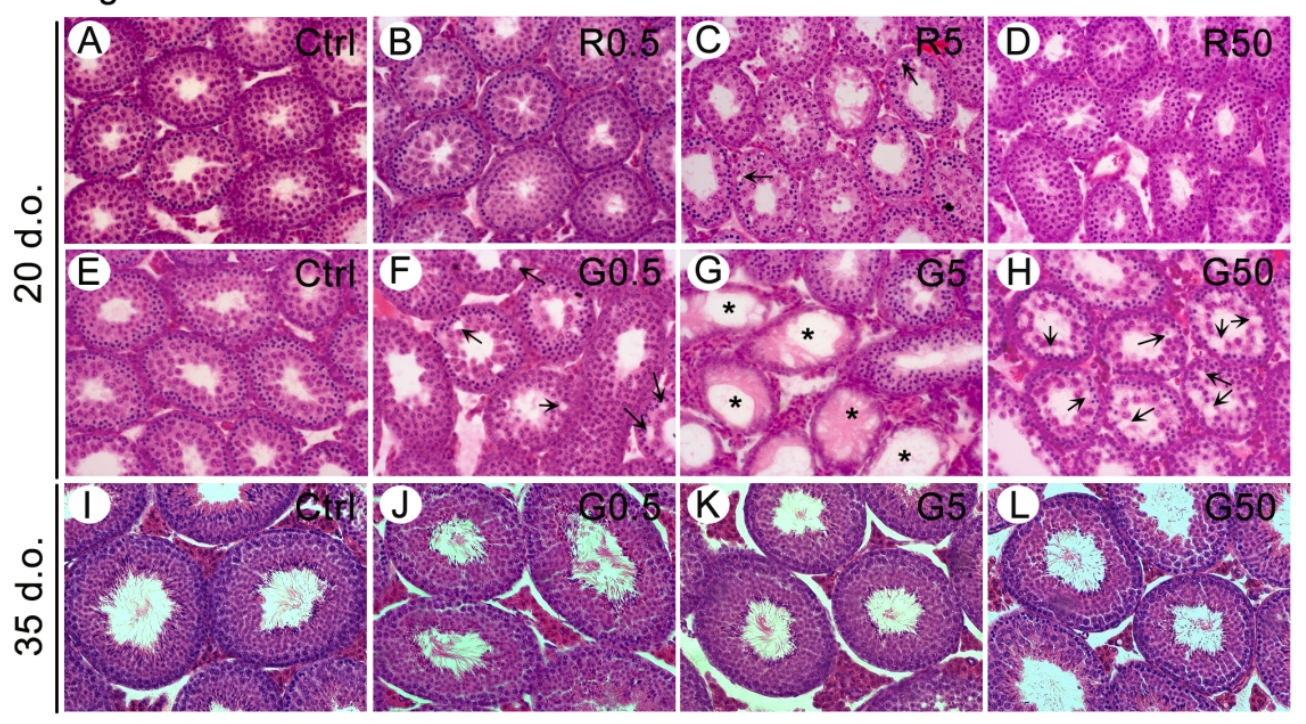

Figure 2: Perinatal exposure to glyphosate and not to a GBH affects the testis morphology in 20 d.o. mice. $H \& E$ staining of the histological sections in $(A-H) 20$ and (I-L) 35 d.o. mice from (A, E and I) ctrl, (B) R0.5, (C) R5, (D) R50, $(F ; J) ~ G 0.5,(G ; K) ~ G 5$ and $(H ; L) ~ G 50$, experimental groups. An increase in vacuoles in the seminiferous epithelium of the testis (arrow) and empty tubules (star) were observed in glyphosate group (G0.5, G5 and G50) compared to control. The presence of vacuoles were observed in R5 group as well. In 20 d.o. mice, $n=5$ for each conditions, in 35 d.o. mice, Ctrl, R0.5, R5, R50, G0.5: $n=6 ; G 5: n=5 ; G 50: n=7$. 
Figure 3
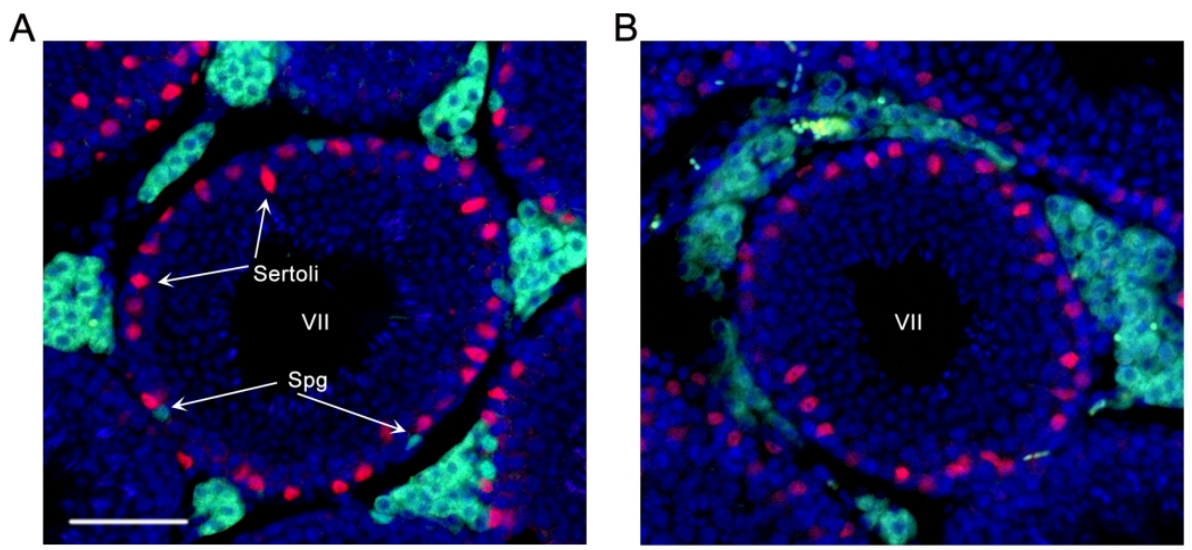

C

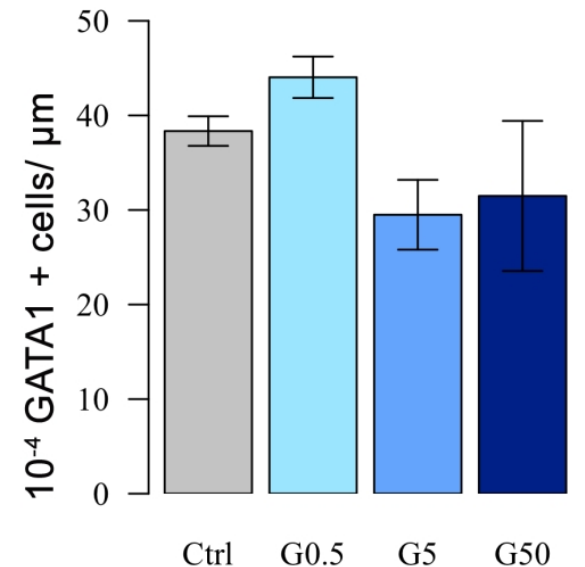

$\mathrm{D}$

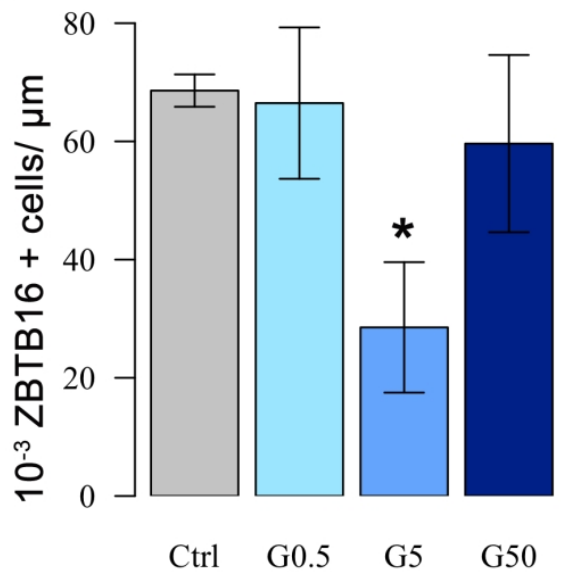

Figure 3: Perinatal exposure to glyphosate decreases the number of undifferentiated spermatogonia in adult mice. Representative images of testes sections from (A) the control (left panel) and (B) glyphosate (G5; right panel) animals: Sertoli cells and spermatogonia ( $\mathrm{Spg}$ ) were immunostained using anti-GATA1 (red) or anti-ZBTB16 (green) antibodies, respectively. The ZBTB16 antibody staining of Leydig cells located outside of seminiferous tubules is non-specific. A quantitative analysis of (C) Sertoli cells and (D) spermatogonia was performed by manually counting the GATA1 and ZBTB16 positive cells at stage VII of the seminiferous epithelium. The contour of each tubule section was measured using ImageJ. The values shown indicate the

cell counts per micrometre of tubule circumference. Values are mean \pm standard error; $n=5$ for all conditions. Statistical analyses were performed using Kruskal-Wallis test followed by Mann-Whitney post-hoc

test to compare the control and treated groups. ${ }^{*} p<0.05, * * p<0.01$ are considered to be significantly different compared to the control group. Scale bar $150 \mu \mathrm{m}$. The immunostaining of the testis sections was performed as described in the Methods section. 
Figure 4
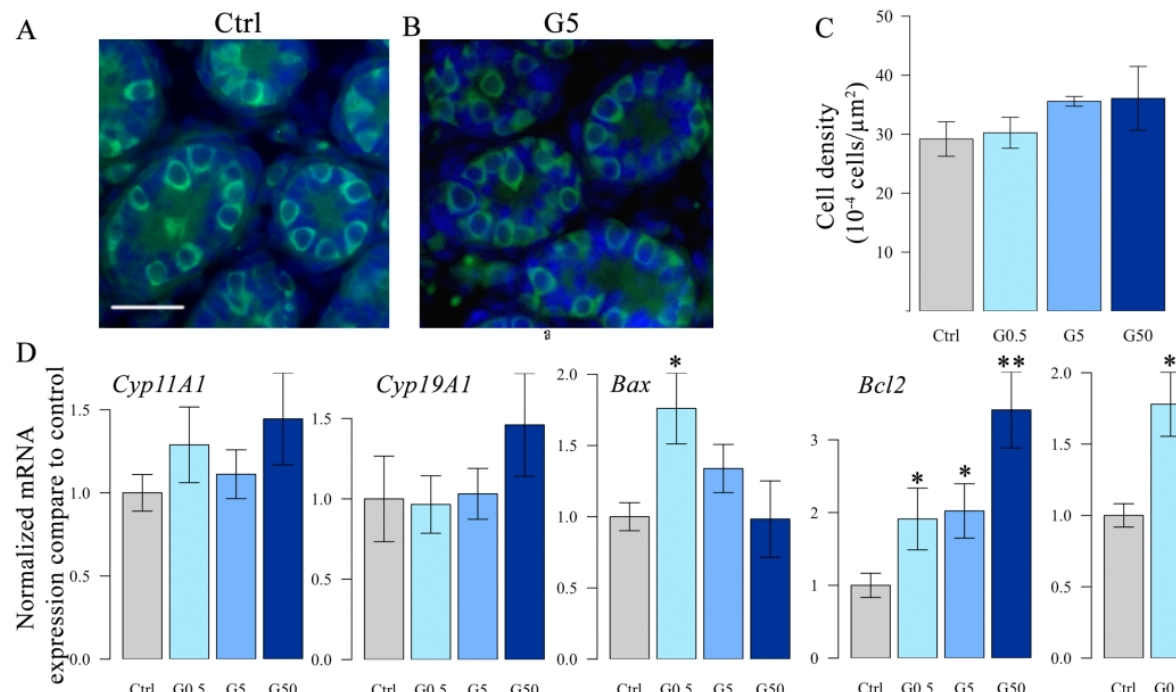

Cyp19A1
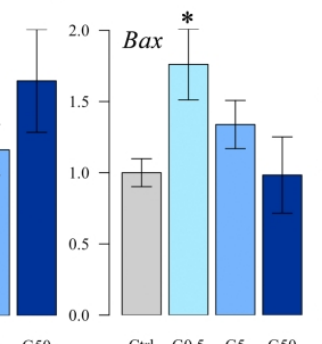

Ctrl G0.5 G5 G50
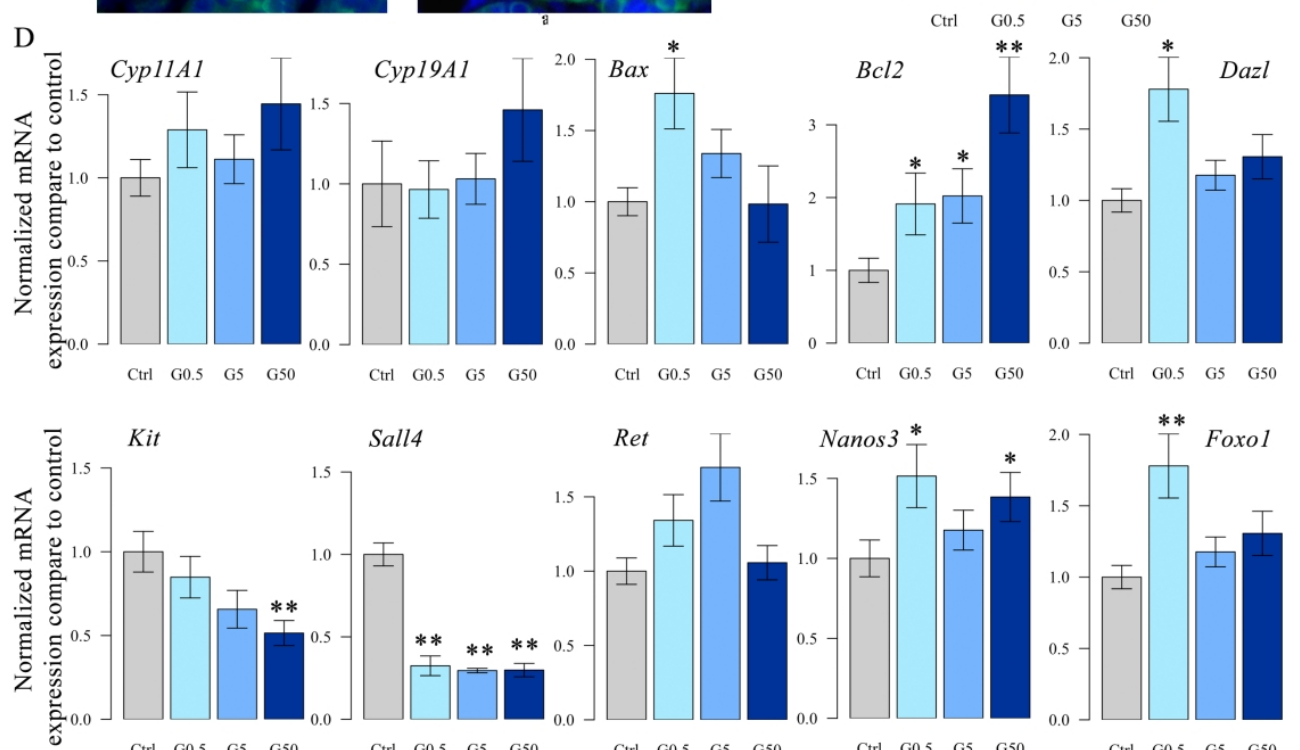

Sall4

Ctrl G0.5 G5 G50

$\begin{array}{llll}\text { Ctrl } & \text { G0.5 } & \text { G5 } & \text { G50 }\end{array}$

$\begin{array}{cccc}\text { Ctrl } & \text { G0.5 } & \text { G5 } & \text { G50 }\end{array}$

$\begin{array}{cccc}\text { Ctrl } & \text { G0.5 } & \text { G5 } & \text { G50 }\end{array}$

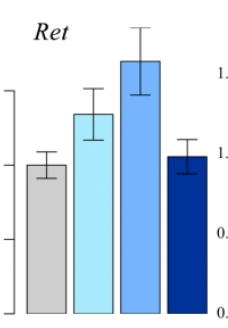

$\begin{array}{cccc}\text { Ctrl } & \text { G0.5 } & \text { G5 } & \text { G50 }\end{array}$

Ctrl G0.5 G5 G50

Figure 4: Perinatal exposure to glyphosate affects the expression of the genes involved in spermatogonia differentiation in prepubertal 5 d.o. mice. Representative images of testes sections from $(A)$ the control (left panel) and (B) glyphosate (G5; right panel) animals: spermatogonia were immunostained using anti-DDX4 (green) antibodies. Scale bar: $40 \mu \mathrm{m}$ (C) Quantitative analysis of the number of spermatogonia showed no any significant differences in 5 d.o. testis. (D) RT-QPCR analysis of RNA expression in control (Ctrl; in grey) and glyphosate groups (G0.5, G5, G50; in bleu). Values are mean \pm standard error. Ctrl, G5, G50: $\mathrm{n}=6$; G0.5: $n=7$. Statistical analyses were performed using Kruskal-Wallis test followed by Mann-Whitney post-

hoc test to compare the control and a treated groups. ${ }^{*} p<0.05, * * p<0.01$ are considered to be significantly different compared to control. The copy numbers of each target gene were normalized to Actb and Rplp0. Data were presented as normalized values compared to control. 
Figure 5
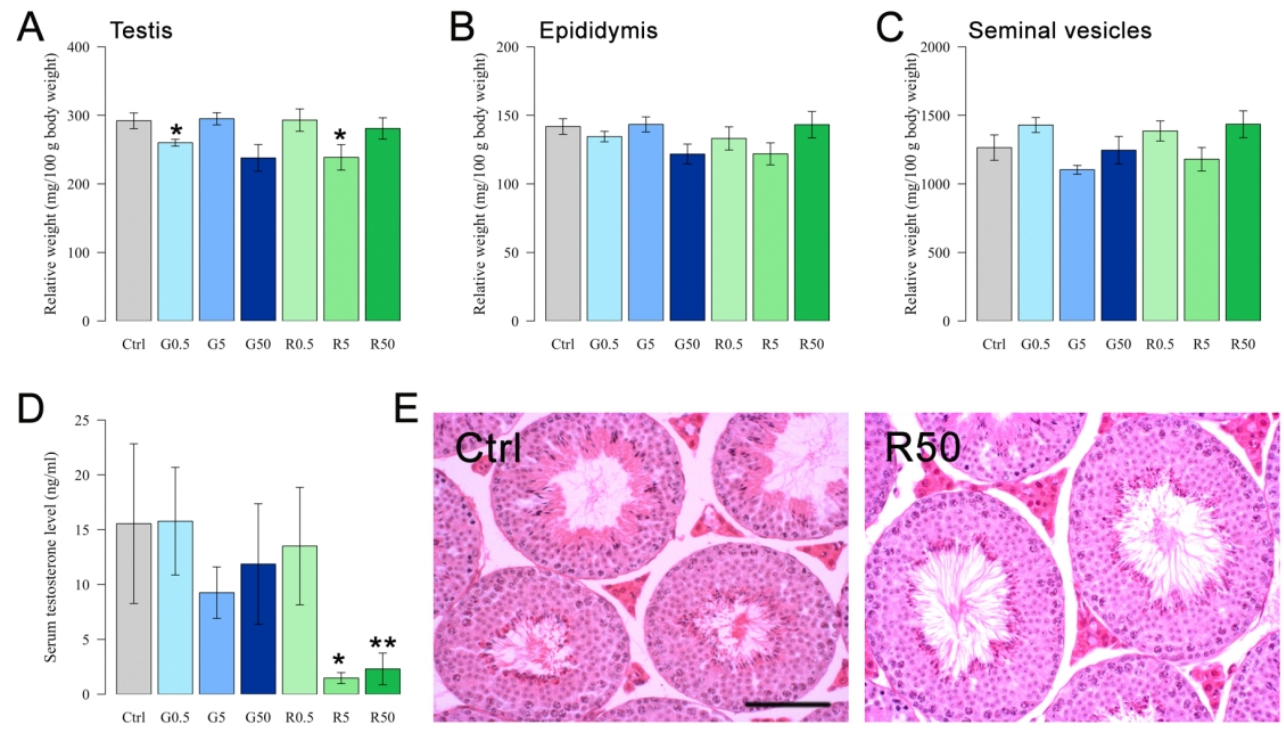

Figure 5: Perinatal exposure to glyphosate and a GBH affects the testis weight and exposure to GBH but not to glyphosate decreases serum testosterone levels in 8 m.o. mice. (A) Testis, (B) epididymis and (C) seminal vesicle weights in 8 m.o. mice derived from females treated with vehicle (ctrl; in grey), glyphosate ( G0.5, G5, G50; in bleu) and a GBH (R0.5, R5, R50; in green). Ctrl: n=6; G0.5: n=13; G5: $n=20 ; \mathrm{G} 50$ : $n=10 ; R 0.5: n=12 ; R 5: n=6 ; R 50: n=8$ (D). The amount of testosterone level in serum were decreased in R5 and R50 groups compared to control. Values are mean \pm standard error; Ctrl: $n=12 ; \mathrm{G0.5:} n=13 ; \mathrm{G} 5$ : $\mathrm{n}=20 ; \mathrm{G} 50: \mathrm{n}=10 ; \mathrm{R} 0.5: \mathrm{n}=12 ; \mathrm{R} 5: \mathrm{n}=6$; R50: $\mathrm{n}=7$. Statistical analyses were performed using KruskalWallis test followed by Mann-Whitney post-hoc test to compare the control group with a treated group. $* p<0.05, * * p<0.01$ are considered to be significantly different compared to control. (E) H\&E staining of the histological sections in 8 m.o. mice from ctrl and R50 experimental groups. Scale bar: 100 $\mu \mathrm{m}$. 